\title{
Könyvismertetö \\ Szántó Richárd, Köves Alexandra, Gáspár Judit, Esse Bálint: Döntések a sportban, Akadémiai Kiadó, Budapest, 2019
}

\author{
DOI: 10.15170/MM.2020.54.03.08
}

Napjainkra a sport a modern társadalmak meghatározó részévé vált. Természetesnek érezzük, ahogy az élet részét képezi és átszövi mindennapjainkat (Ács et al. 2015). Magától értetődőnek tartjuk, hogy kedvünkre válogathatunk számos sportolási lehetőség közül számtalan sportágban, amikhez még a szükséges infrastruktúra is rendelkezésre áll. Számunkra kedves sporteseményeket és sportolókat tekinthetünk meg élőben a rendezvények helyszínén vagy a médián keresztül, ahol a versenyek izgalmai közepette életre szóló élményekkel gazdagodhatunk. Ha pedig egy fárasztó nap után egy kis kikapcsolódásra vágyunk és bekapcsoljuk a televíziót, napszaktól függetlenül válogathatunk számos sportcsatorna kínálatából.

A múltba visszatekintve ez korántsem volt mindig így, de az elmúlt évtizedekben a sport népszerüségének növekedése rengeteg sporthoz kapcsolódó lehetőséggel gazdagította a szabadidőben végezhető tevékenységek palettáját (Szakály \& Fehér 2015), felértékelte a sportfogyasztás témakörét (Csóka \& Törőcsik 2019, Neulinger 2007). A sport népszerüségének világszintủ növekedése jelenleg is töretlen, így a felsorolt példákon túl az élet számos egyéb területével is összekapcsolódik. A társadalom szempontjából a sportnak kiemelt szerepe van a gazdaságban, a közoktatásban, az egészségmegőrzésben, a turizmusban, és a média egyes területein is (Laczkó \& Rétsági 2015). Laczkó és Rétsági $(2015,7)$ szerint a sport „Növekvő társadalmi jelentösége, melyet a társadalmi és a politikai diskurzusban való egyre eröteljesebb jelenléte is bizonyít, hazánkban is megteremtette az igényt, e sajátos terület jellemzöinek és müködésének minél szélesebb körü megismerésére, illetve megismertetésére."

Ebben a folyamatban, azaz a sportvilág müködésének megismerésében Szántó és társai Döntések a sportban címü 2019-ben megjelent könyve hiánypótló mủ a hazai szakirodalomban. Ahogy fentebb jeleztük, a sport az élet több területét is érinti. Ezzel összhangban a sporttudományok erösen multi- és interdiszciplináris jellegűek, számos tudományterületet érintenek (Tihanyi 2006). Szántó és társai könyve ezeken átívelve, nem egyes tudományterületekre koncentrálva mutatja be az érintett csoportok döntési sajátosságait és döntési hibáit. Értékes olvasmányt jelenthet ez mindazok számára, akik szeretnék jobban megérteni a sport világának müködését. Különösen értékes információkat rejthet a könyv olyan szakembereknek, akik sportszervezetek és sportolók életében hoznak döntéseket napról napra. A könyvben összegyüjtött tudásanyag segítségével javíthatják döntési hatékonyságukat, és így elkerülhetnek számos, a korlátozott racionalitásból eredő döntési hibát.

A könyv címe a Döntések a sportban egyszerü, lényegre törő és elöre vetíti, hogy a fejezetekben bemutatott sporttal kapcsolatos döntési szituációk több ponton kapcsolódnak különböző döntéselméleti témakörökhöz. A könyv összesen tizenhárom fejezetből tevődik össze, amiből az első fejezet egyfajta bevezetésnek tekinthető. Ebben a szerzők bemutatják, hogy a sport világában egymástól jelentősen eltérő szereplők miképp alkotnak igen komplex rendszert. Ebben a számtalan érintett egymással összefüggő hálózatként értelmezhető, mivel az érintettek döntései hatással vannak a többi érintettre is, és amely hatás egyes esetekben igen jelentős is lehet. A sportszervezeteknek emiatt a müködésük során nemcsak tudniuk kell, hogy a környezetükben mely szereplők azok, akik igazán számítanak, hanem döntéseik során figyelembe is kell venniük őket. Ennek gyakorlati megvalósításához nyújt lehetöséget a 80-as években Freeman által kidolgozott érintettelmélet. Szántó és társai szerint a döntéshozók javíthatják döntéshozatalaik hatékonyságukat és ezáltal eredményességüket az érintettelméletet alkalmazva. Az első fejezetből kiderül, hogy a szerzők a könyvet az érintettelmélet szemléletében írták, aminek helyes alkalmazása akár egy nemzet szintjén is segítheti a sport fejlődését. Ugyanakkor arra is felhívják a figyelmet, hogy alkalmazása önmagában még nem jelenti azt a sportszervezetek esetén, hogy a gyakorlatban az érintettcsoportok érdekeit valóban figyelembe is vennék a döntéshozatal során. Ráadásul, mivel a sport környezete igen komplexnek tekinthetö, a döntéshozók pedig minden esetben rendelkeznek valamilyen egyéni kognitív korlátokkal, ezért még akkor sem lehet tökéletes, teljesen racionális döntéseket hozni, ha a döntéseket az érintettekkel együttmüködve hozzák meg. Az érintetteket ennek ellenére megéri bevonni a döntéshozatali folyamtokba, mert ugyan így sem lehet tökéletes döntéseket hozni, de a döntések minősége ezzel hosszú távon egyértelmúen javítható. Az első fejezetet követő fejezetekben a szerzők tíz különböző, sporthoz kapcsolódó érintett 
csoport döntési sajátosságait mutatják be, részletesen foglalkozva azok leggyakoribb döntéshozatali csapdáival, illetve etikai kérdéseivel.

A második fejezetben a sportolók esetén tapasztalható döntési sajátosságokkal ismerkedhetünk meg. Legyen szó bármilyen sportolóról, a sikerükhöz nem elegendő, ha pusztán képesek technikailag jól végrehajtani az összes sportágukhoz kötődő gyakorlatot. Mellette képesnek kell lenniük a megfelelö pillanatban megfelelö döntéseket hozni, felismerni, hogy adott helyzetben mi legyen a következö lépésük. A jó eredmény érdekében számukra a technikai tudással egyenlően fontossá válik az észlelés és kivitelezés képessége. Ami igazán nehézzé teszi ezt, az az, hogy az aktív helyzetekben (játék közben, mérkőzésen, versenyhelyzetben) hozott döntések különböző mértékủ mentális és fizikai terhelés alatt születnek sportágtól függően. Érdekes módon az élsportolók az átlagemberekkel ellentétben nem hoznak rosszabb minőségü döntéseket terhelés alatt annál, mint amilyeneket terhelés mentes állapotban hoznának. Ez annak köszönhetö, hogy tudatos edzésmunkával nemcsak a technikai tudásukat fejlesztik, hanem a döntéshozatali képességet, a reakcióidőt, és az információfeldolgozási sebességet is.

A harmadik fejezetben olyan döntési helyzetekröl olvashatunk, amikkel az edzök kerülnek szembe a mindennapi munkájuk és karrierjük során. A sportesemények nézői nagyon gyakran szoktak véleményt alkotni az edzők döntéseiről, arról, hogy egyes helyzetekben az edzőnek mit vagy éppen mit nem kellet volna tennie. Teszik mindezt annak ellenére, hogy az esetek döntő többségében egyáltalán nem látják át az edzői döntések komplexitását, csak találgatnak a helyes döntést illetően. Amúgy is nehéz meghatározni, mik tartoznak pontosan egy edzőnek a feladatai közé, hiszen a helyzettől függően egymástól nagyon eltérő szerepekben lehet jelen. Ez tovább nehezíti az edzők döntéseinek megértését. A fejezet ebben nyújt segítséget azáltal, hogy részletesen bemutatja magát a környezetet, amiben az edzők dolgoznak, a feladatokat, amiket el kell végezniük, illetve a szerepeket, amiket egyes esetekben magukra kell vállalniuk. Ez igen érdekes témakört jelent, hiszen egy edzőnek sokszor a folyamatok menedzsmentje mellett egyszerre kell foglalkoznia a sportolói motiválásával, a játékosok közötti társas kapcsolatokkal és a külső kapcsolatok ápolásával. Ennek kézbentartásához az edzőknek igen speciális készségekre és képességekre van szükségük, hogy olyan döntéseket hozhassanak, amik segítségével a munkájukat sikeresen el tudják látni.

A negyedik fejezetben a bírók döntési jellemzőivel ismerkedhetünk meg, amiből kiderül, hogy a legtöbb sportágban a bírók sokkal több döntési helyzettel kénytelenek szembenézni, mint azt elsőre gondolnánk. Ráadásul, ezeket a döntéseket sokszor a sportolókhoz hasonlóan, mentális és fizikai terhelés mellett kell meghozniuk. Gondoljunk csak a bírók helyzetére a labdarúgásban, ahol folyamatosan kell futniuk a pályán, mivel az egyes helyzeteket az ítéletalkotáshoz a legjobb szögből kell látniuk. A fejezetből kiderül, hogy a bírók személyisége, motivációi és felkészültsége miként befolyásolja a döntéseiket és azok helyességét. Ezekkel az információkkal pedig nemcsak maguknak a bíróknak fontos tisztában lenni, hanem az egyes versenyek, mérkőzések rendezőinek is a rendezvényekhez leginkább megfelelö bírók kiválasztásában. Hiszen egy-egy rossz bírói döntés nemcsak az adott bírónak a karrierjére nyomhatja rá a bélyegét, de a nézők számára is negatív irányba befolyásolhatja a nyújtott élményt.

A sportélmények elsőszámú fogyasztói egyértelmủen a szurkolók. Szerepüket elsőre talán passzívnak gondoljuk, de a sportcsapatok és sportolók profittermelő képességét és ezáltal megélhetését alapjaiban befolyásolják a szurkolók döntései. Kezdve attól, hogy szurkolóvá válik-e valaki, egészen addig, hogy elveszti-e a lelkesedését és befejezi-e a szurkolást. Az ötödik fejezetben a szurkolói döntéseket befolyásoló tényezőkröl olvashatunk, mint a szurkolás mögöttes motivációiról vagy arról, minek a hatására dönt valaki úgy, hogy élőben a helyszínen tekint meg egy sporteseményt. Érdekes témakört jelent a fejezet végén az esélyteleneknek való szurkolás társadalmi motivációinak bemutatása is. Ha Dávid és Góliát módjára esélytelen sportoló vagy csapat küzd meg egy nála sokkal erősebb ellenféllel, akkor a szurkolók nagy része hajlamos a gyengébb félnek szurkolni.

A hatodik és a hetedik fejezetekben a szponzorok és a média döntési sajátosságai jelennek meg. A sport egyértelmúen a médiának köszönhetően érte el azt a népszerüségét, amit napjainkban tapasztalhatunk. A média tette lehetővé, hogy a sport széles rétegekhez eljusson különböző csatornákon keresztül, és megteremtse az igényt a sportesemények megtekintése mellett az aktív sportolásra is. Ezzel párhuzamosan a szponzorációban rejlő lehetőségek is kiszélesedtek, hiszen ma már egy-egy rangosabb sporteseményt vagy sportolót a médián keresztül világszinten akár tízmilliók követhetnek figyelemmel. A szponzoroknak, mint profitorientált szereplőknek ez gyümölcsözővé teszi a szervezetek, csapatok, sportolók, helyszínek szponzorálását, hiszen márkájukat és márkaüzenetüket a szponzorálással széles körben tudják kommunikálni. A két fejezetben a szerzők bemutatják, hogy milyen motivációkkal rendelkeznek a média egyes szereplői és a szponzorok a sportban való megjelenésükben, illetve azt is, hogy ezeken a területeken a döntéshozóknak 
milyen kockázatokkal kell szembenézniük. Ezek a kockázatok a média torzító hatásából következik, míg a szponzoráció esetén inkább az etikai kérdések aggályosak.

A kockázatok kérdése a sporthoz kapcsolódóan leggyakrabban mégsem a média vagy a szponzoráció kapcsán szokott előtérbe kerülni, sokkal inkább a sportfogadáshoz köthetően. A számos etikai aggály ellenére a sportfogadások beépültek a sportvilág mindennapjaiba, ezek létezését a társadalom nagy része teljesen természetesnek tartja. A könyv nyolcadik fejezete a sportfogadót és a bukmékereket veszi górcső alá, mint érintetteket, akik a fogadásokhoz kapcsolódóan döntéseket hoznak. Ezeknek a döntéseknek az az érdekessége, hogy több esetben igen nagy tétjük lehet akár a sportfogadók (sok esetben az anyagi helyzetüket is kockáztathatják), akár a bukmékerek (egy rossz döntés az állásukat veszélyeztetheti) szempontjából. A sportfogadók döntései alapjaiban különböznek attól függően, hogy a fogadások során a pénznyerési lehetőség vagy a szurkolási izgalom növelése motiválja öket. Előbbi csoport nagyobb arányban használ statisztikai adatokat annak megállapítására, hogy kire érdemes fogadni, míg utóbbi csoport szívesebben fogad egyszerủen a kedvenc csapatára vagy sportolójára, hogy növelje a szurkolás közben saját izgalmát. Néhány esettől eltekintve azonban egyértelmü, hogy összességében nem a sportfogadók, hanem a bukmékerek azok, akik képesek hosszú távon nyereségesen müködni. Ezt a nyerési esélyek meghatározásánál hozott döntéseiknek köszönhetik.

A könyv kilencedik fejezetében a sporthoz kapcsolódó politikai döntésekről és politikus döntéshozókról olvashatunk. A sport jelentős társadalmi értékkel rendelkezik, emiatt nehezen választható el a hozzá kapcsolódó kulturális és ideológiai szerepektől. Társadalmi jelentősége egyre inkább nyilvánvaló, ami miatt a sport a gazdaság mellett a politikával is összefonódik. A politika a sportot saját érdekeinek megfelelően alakíthatja, a sportszervezetek támogatása pedig sokszor a politikusok kegyeitől függ. Az sem számít ritka jelenségnek, hogy a politikusok a környezetük sportsikereit a saját érdemeikként tüntetik fel, mintha kulcszszerepük lett volna azok elérésében. A fejezet részletesen bemutatja a politikai döntéshozók szerteágazó motivációit, az információfeldolgozási sajátosságaikat, az egyéni döntéseiket befolyásoló tényezőket, és a sporthoz kötődő korrupciós döntéseik jellemzöit is.

A tizedik fejezet az utánpótlás-nevelés témakörében a gyermekkori, ifjúsági sportolás és az élsportolóvá válás társadalmi, pszichológiai és kulturális beágyazottságának dilemmáit mutatja be. A gyakori sportolás az egészséges fejlődés egyik sarkalatos pontja, ami gyermekkortól kezdve számos képességet és készséget fejleszthet sportágtól függően. A megfelelő sportolási lehetőség biztosítása és a megfelelő sportág kiválasztása nagy felelősséget jelent mind a szülők, mind az utánpótlásért felelős szakvezetők számára. A szerzők a fejezetben bemutatják, hogy a sportolás kezdetétől számos döntést kell meghozni, amik során figyelembe kell venni a fiatal sportoló céljait, tehetségét, képességeit és készségeit is. Felhívják a figyelmet az utánpótlás-nevelés üzletszerüségére, illetve a szülők túlzott elvárásaira is, ami többször nemcsak rossz hatással lehet a fiatal sportoló életminőségére, hanem akár korai kiégéséhez is vezethet.

A sport üzletté válásának és egyre meghatározóbb társadalmi szerepének köszönhetően nem szabad megfeledkeznünk a sport helyi közösségekre és a természeti környezetre gyakorolt hatásáról sem. A tizenegyedik fejezetben a szerzők bemutatják, hogy a sporthoz kapcsolódó döntéshozóknak a döntéseik fenntarthatóságát is szem előtt kell tartani, csakúgy, mint a sportesemények és sportlétesítmények ökológiai lábnyomát. Az utóbbi időben a sporthoz köthető környezetkárosítás egyes esetekben riasztóan nagy mértékeket öltött és számos helyi közösség számolt be negatív hatásokról is. A fenntartható szemlélet zászlóshajójaként a világ egyik legnagyobb sporteseménye, az olimpia is a környezettudatos müködést helyezte fokozatosan elötérbe. Ennek fényében napjainkban csak olyan város nyerheti el a rendezés jogát, ami komoly fenntarthatósági tervekkel rendelkezik.

A tíz különböző érintettcsoport bemutatása után a szerzők a tizenkettedik fejezetben egy módszert ismertetnek, amivel növelhető a döntések minősége és pontossága. Ez a módszer a részvételi döntéshozatalt jelenti, amivel szemléltetik, hogy milyen előnyökkel és hátrányokkal járhat az egyes érintett csoportok megfelelö bevonása a döntéshozatali folyamatokba. A részvételi döntéshozatal működésének megértése segítséget nyújthat a gyakorlati szakemberek számára abban is, hogy milyen mélységben és hogyan célszerü bevonni az értintetteket a döntéshozatali folyamataikba. Óva intenek azonban a szerzök az érintettek látszólagos bevonásától, amikor ugyan a döntéshozatali folyamatokba bevonják őket, a valóságban azonban a döntéshozók a megkérdezettek véleményétöl függetlenül döntenek. Ez könnyen a visszájára fordulhat és jelentős károkat okozhat az érintettek csalódottságából eredő haragja miatt.

A könyv tizenharmadik és egyben utolsó fejezete a sport jövőjének kérdését tárgyalja, amiben a szerzők nem bocsátkoznak se túl optimista, se túl pesszimista elörejelzésekbe. A fejezet objektíven próbálja összegyüjteni a sportot a közeljövőben meghatározó, de már ma is felfedezhetö trendeket. Olvashatunk 
az emberi test jövőbeli változásairól, amiben a testrészek változási mellett a bionikus kiegészítőkről is szó esik. Ehhez kapcsolódóan feltételezhetően az edzésmunka is megváltozik majd és egyre több technológiai újítás segíti a versenyekre, illetve a mérkőzésekre való eredményes felkészülést. A fejezetben tárgyalásra kerül a természeti környezet, amiben a sporthoz kapcsolódóan a legnagyobb befolyásoló a klímaváltozás lesz. A szerzők bemutatják azt is, hogy a sport jövője nem független a tartalomfogyasztási szokásoktól sem, amiben egyértelmủen a kiterjesztett és a virtuális valóságnak lehet kimagasló szerepe. A fejezet tanulságaiból kiemelendő, hogy sport világa nem állandó, az egyes sportágak népszerúsége is folyamatosan változik. Egyes sportok eltünnek, míg mások, mint a jelenleg népszerủ e-sportok látszólag a semmiből tủnnek fel és rövid idő alatt világszintủ népszerüségre tesznek szert.

Összefoglalásként a könyv talán legnagyobb tanulsága, hogy döntéshozóként a sporthoz kapcsolódó döntésekben is megéri széleskörúen végiggondolni, kik lehetnek azok érintettjei. A velük való kommunikáció segítségével olyan megvilágosító erejü információk birtokába is kerülhetünk, amelyek teljesen új fényben tüntethetik fel a döntéshez való viszonyulásunkat vagy éppenséggel megerősíthetik eredeti elképzelésünket. Az értintettek megfelelő döntéshozatali folyamatba való bevonásának segítségével teret engedünk annak, hogy az egyes problémákra a megoldást azok találják meg, akik a legszélesebb körben ismerik a probléma természetét. Ebben az a nagyszerü, hogy a döntések minősége összességében javul, miközben a sportvezetôn csökken az a nyomás, hogy mindenhez neki kell a legjobban érteni.

Csóka László, PhD hallgató csoka.laszlo@ktk.pte.hu Pécsi Tudományegyetem

\section{HIVATKOZÁSOK}

Ács P., András K., Farkas F., Fazekas A., Gyömörei T., Jarjabka Á., Paár D., Rappai G., Sterbencz T., Stocker M., Szabó Á., Szilágyi L., Tamás L. (2015), Sport és gazdaság, Pécsi Tudományegyetem Egészségtudományi Kar, Pécs

Csóka L., Törőcsik M. (2019), „A sportfogyasztás és a sportmotivációt mérő skálák", Marketing \& Menedzsment, 53(EMOK különszám), 77-86 DOI: 10.15170/MM.2019.53.EMOK.08

Laczkó T., Rétsági E. (2015), A sport társadalmi aspektusai, Pécsi Tudományegyetem Egészségtudományi Kar, Pécs
Neulinger Á. (2007), Társas környezet és sportfogyasztás. A folyamatos megerősítést igénylö tanult fogyasztás, Doktori (PhD) értekezés, Budapesti Corvinus Egyetem, Gazdálkodástani Doktori Iskola, Budapest

Szakály Z., Fehér A. (2015), Sportmarketing. „ABS” Képzés- és rendszerfejlesztés a sportos társadalomért Észak-Kelet Magyarországon (A és B komponensek a felsőoktatási Sport fejlesztéséért) TÁMOP-4.1.2.E-13/1/KONV-20130010

Tihanyi J. (2006), A sporttudomány jelene és jövője, Az Eszterházy Károly Föiskola tudományos közleménye, Testnevelés, sport, egészségturizmus, 5-10 